\title{
Xenomys nelsoni predation by the snake Senticolis triaspis in México
}

\section{Depredación de Xenomys nelsoni por la serpiente Senticolis triaspis en México}

\author{
Patricia Hernández-López ${ }^{1}$, Ángel Rodríguez-Moreno ${ }^{2}$, and José L. Jaramillo-Alba ${ }^{3 *}$ \\ ${ }^{1}$ Parque Nacional Lagunas de Chacahua, CONANP. La Grúa Chacahua sin número, CP. 71800, Oaxaca. Oaxaca, México. Email: \\ patricia.hernandez.lopez.01@gmail.com (PH-L). \\ ${ }^{2}$ Departamento de Zoología, Instituto de Biología, UNAM. Ciudad Universitaria, 70-153, CP. 04510, Ciudad de México. Ciudad de \\ México, México. Email: angelrodriguezmoreno14@hotmail.com (AR-M). \\ ${ }^{3}$ Facultad de Estudios Superiores Iztacala, UNAM. Avenida de los Barrios 1, CP. 54090, Iztacala. Estado de México, México. Email: \\ jaramillo.luis@ciencias.unam.mx (JLJ-A). \\ ${ }^{*}$ Corresponding author
}

Dry jungles harbor a large number of species with restricted distribution or endemic, and little is known about the ecological processes involving these species. Such as activity periods, diet, or predation. In October 2016, we registered a predation event on the Mexican endemic rodent Xenomys nelsoni by the colubrid snake Senticolis triapsis in the Chamela-Cuixmala Biosphere Reserve. This rodent species is listed as endangered by the Mexican law. This is the first report of predation on individuals of this threatened rodent genus.

Key words: Colubridae; diet; dry forest; endemic rodent; predation.

Las selvas secas albergan un gran número de especies endémicas y con distribución restringida, de las cuales se sabe poco sobre los procesos ecológicos en donde participan. Como por ejemplo, los períodos de actividad, dieta, o interacciones con los depredadores. En octubre de 2016, registramos un caso de depredación del roedor endémico de México Xenomys nelsoni por el colúbrido Senticolis triaspis en la Reserva de la Biosfera Chamela-Cuixmala. Esta especie de roedor está considerado como especie amenazada por la ley mexicana. Este es el primer reporte en campo, de depredación a individuos de este género de roedores amenazado.

Palabras clave: Colubridae; depredación; dieta; roedor endémico; selva seca.

(c) 2020 Asociación Mexicana de Mastozoología, www.mastozoologiamexicana.org

Dry forests are ecosystems that harbor a large number of endemic species (Ceballos and García 1995), many of which are species with restricted distribution (Arita et al. 1997). These ecosystems are natural laboratories that have been extensively studied (e. g., the Chamela-Cuixmala region, México). However, some of the species inhabiting these areas have not been sufficiently investigated (Miranda 2002a); consequently, information gaps still remain regarding the ecological processes involving these species, e. g., reproduction, periods of activity, diet, and others.

Knowledge about the feeding habits is essential to understand predator-prey relationships. However, the diet of taxa characterized by cryptic habits is poorly known, as is the case of snakes. In general terms, recorded prey include other reptiles (lizards and snakes), birds, and mammals (Seigel et al. 1987).

This paper reports the first record of predation on the arboreal rat Xenomys nelsoni by the snake Senticolis triaspis, a species of terrestrial and arboreal habits (Hammerson et al. 2015) that displays activity in twilight hours in captivity (Radke and Malcolm 2008). The diet reported for S. triaspis includes small mammals such as rodents of the genera Mus, Peromyscus, and Neotoma (Degenhardt et al. 1996; Radke and Malcolm 2005).
The Chamela-Cuixmala Biosphere Reserve is located on the west coast of Jalisco, México $\left(19^{\circ} 29^{\prime} \mathrm{N},-105^{\circ} 01^{\prime} \mathrm{W}\right)$. Mean annual precipitation is $798 \mathrm{~mm}$, and mean annual temperature is $24.6^{\circ} \mathrm{C}$ (García-Oliva et al. 2002). Altitude ranges from 0 to 500 meters above sea level, and the vegetation corresponds to tropical deciduous forest and medium subdeciduous forest (Bullock 1986). A total of 64 rodent species have been recorded for the state of Jalisco (Godínez and Guerrero 2014), with 13 species of rodents (Miranda 2002a) and 63 species of reptiles (Ramírez-Bautista 1994) in the reserve.

From 10 to 19 October 2016, night walkthroughs were conducted (20:00 to 00:00 h) where the predation event reported in this note was incidentally recorded. The snake was identified to species at the Chamela-Cuixmala Biological Station and subsequently released; regurgitated prey specimens were identified by comparison with samples in the National Collection of Mammals of the Institute of Biology, UNAM.

On 18 October 2016, at 21:24 h in the Chamela-Cuixmala Biosphere Reserve ( $\left.19^{\circ} 29^{\prime} 58.95^{\prime \prime} \mathrm{N},-105^{\circ} 2^{\prime} 32.59^{\prime \prime} \mathrm{W}\right)$, we found an individual of Senticolis triaspis (Ramírez-Bautista 1994; $1.175 \mathrm{~mm}$ total length and $205 \mathrm{~g}$ total weight) falling from a tree branch while preying on Xenomys nel- 
soni (Figure 1a). The snake also showed distension of the middle part of its body, indicating the presence of a second prey undergoing digestion. Upon noticing the lamp lights, the snaked loosened the prey from its jaws; four hours after being captured, it regurgitated the second prey (Figure $1 \mathrm{~b}$ ).

The two prey individuals corresponded to juveniles of the rodent Xenomys nelsoni. Both were identified to species based on the presence of taxonomically distinctive morphological traits (Álvarez-Castañeda et al. 2015). Externally, both specimens display white spots in the eyes, a unique feature that is absent in all other cricetid rodent species living in Mexico. The pelage of the ventral region is white; the monochromatic tail is shorter than the head and body. As to the characteristics of the skull, auditory bullae are large, which is also a distinctive trait. Both $X$. nelsoni specimens were deposited in the National Collection of Mammals with catalog numbers CNMA 49520 and 49521.

Xenomys nelsoni is a species endemic to Mexico, characterized by strictly nocturnal and arboreal habits (Schaldach 1960). It lives exclusively in thorny forests and tropical deciduous forests, in areas with high tree density and closed canopy (Schaldach 1960; Ceballos 1989, 2005; Miranda 2002b). Xenomys nelsoni is a rodent of which little is known, listed as
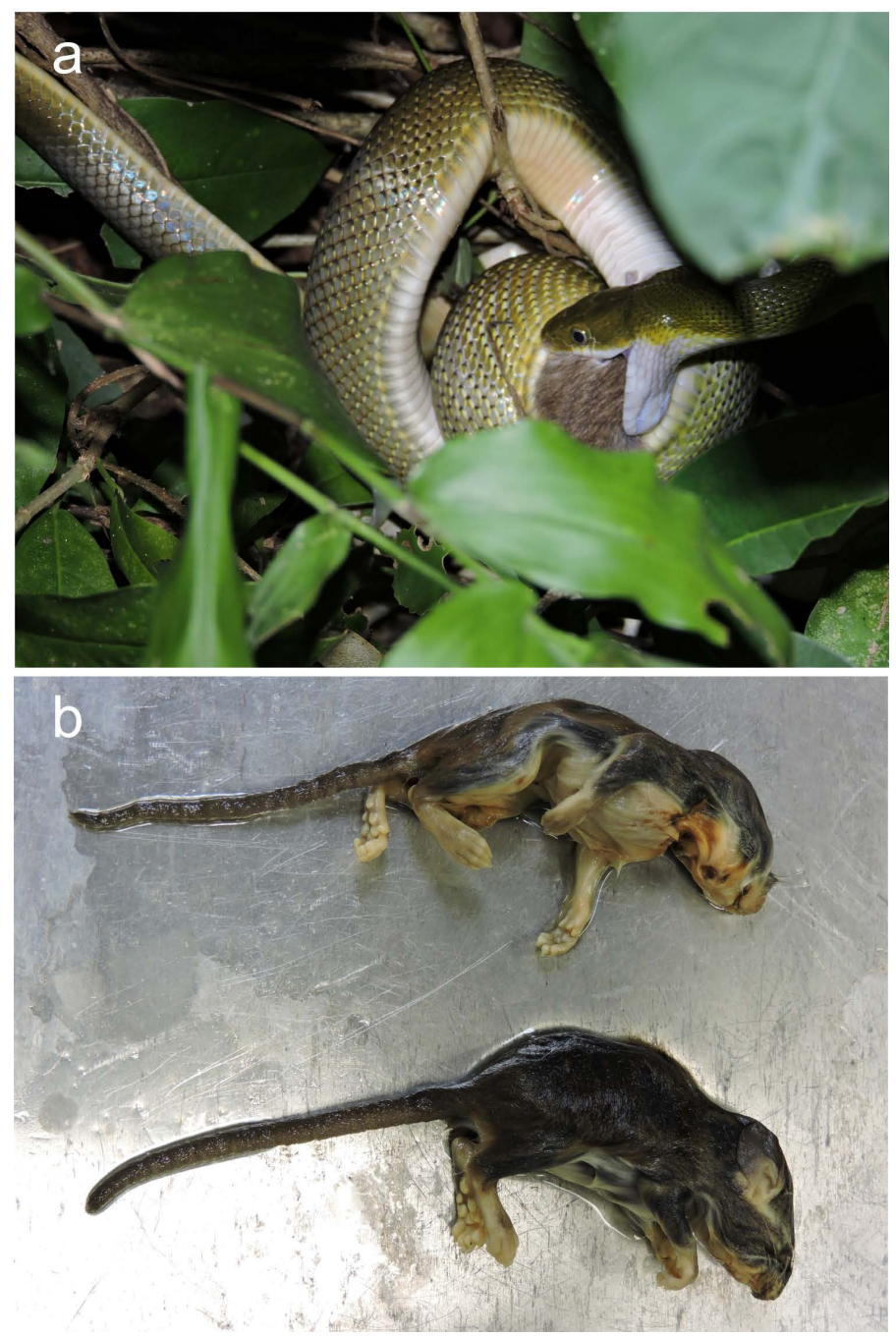

Figure 1. a) Adult individual of Senticolis triaspis feeding on the rodent Xenomys nelsoni, b) Juvenile specimens of $X$. nelsoni. threatened by the Secretaría de Medio Ambiente y Recursos Naturales (SEMARNAT 2010) and as Endangered A2c by the International Union for the Conservation of Nature (Vázquez 2018). Its critical conservation status relates to its restricted distribution and the deforestation of its natural habitat (Ceballos 1989; Arita et al. 1997; Ceballos et al. 2002).

There is little information available on the ecological aspects of $X$. nelsoni; some specimens have been collected on trees of Trichilia cf. hirta, Annona reticulata, Bursera simaruba, Castilla elastica, and Calocarpum mammosum (Schaldach 1960; Ceballos et al. 2002). Previous studies suggest that the reproductive period of $X$. nelsoni occurs in the dry season and in the rainy season from May to November (Ceballos and Miranda 2000). This species nests in hollow trees and has a litter size of two young (López-Forment et al. 1971).

Nests of $X$. nelsoni can be found in tree cavities (ValdiviaHoeflich et al. 2005) and branches of Trichilia cf. hirta at 10 to 13 meters high (Schaldach 1960). However, it is currently unknown whether the nests found correspond to $X$. nelsoni, Nyctomys sumichrasti, or Handleyomys melanotis (Domínguez-Castellanos et al. 2007). Considering the litter size reported, both specimens of $X$. nelsoni may have been preyed on or near the nest, since they were juveniles. The $S$. triaspis individual was spotted in the closed canopy of the low deciduous forest, a habitat where the presence of nests of $X$. nelsoni has been reported in the literature (ValdiviaHoeflich et al. 2005).

Although it is thought that the potential natural predators of $X$. nelsoni include snakes, birds of prey, and medium-sized mammals, no previous observational data on the predators of this species had been noted before this report (Schaldach 1960; Ceballos 1989; Ceballos and Miranda 2000; Domínguez-Castellanos et al. 2007). In this sense, this report represents the first direct evidence of predation of $X$. nelsoni, and also provides information on the diet of the snake $S$. triaspis, hence contributing data on the interactions between both species in the ecosystem.

\section{Acknowledgements}

We wish to thank H. A. Perez Mendoza, A. Diaz de la Vega and the staff of the Chamela-Cuixmala Biological Station IB-UNAM, for their assistance provided, to J. Vargas C. for assistance in the taxonomic determination of the $X$. nelsoni specimens at the CNM, UNAM. M. E. Sánchez translated the manuscript into English.

\section{Literature cited}

Álvarez-Castañeda, S. T., Álvarez, T., and N. González-Ruiz. 2015. Guía para la identificación de los mamíferos de México en campo y laboratorio. Centro de Investigaciones Biológicas del Noroeste, S. C., Asociación Mexicana de Mastozoología, A. C. Ciudad de México, México.

Arita, H. T., F. Figueroa, A. Frisch, P. Rodríguez, and K. SantosDel-Prado. 1997. Geographical range size and the conservation of mexican mammals. Conservation Biology 11:92-100. 
BuLlock, S. H. 1986. Climate of the Chamela Jalisco and trends in south coastal region of Mexico. Archives for Meteorology, Geophysics, and Bioclimatology, Series B 36:297-316.

Ceballos, G. 1989. Population and community ecology of small mammal from tropical deciduous and arroyo forest in western Mexico. Ph.D. dissertation, University of Arizona. Tucson, Arizona.

Ceballos, G. 2005. Xenomys nelsoni. Pp. $809-810$ in Los mamíferos silvestres de México (Ceballos, G., and G. Oliva, eds). CONABIO/Fondo de Cultura Económica, Ciudad de México, México.

Ceballos, G., and A. García. 1995. Conserving neotropical biodiversity: the role of dry forests in western Mexico. Conservation Biology 9:1349-1353.

Ceballos, G., and A. Miranda. 2000. Guía de campo de los mamíferos de la costa de Jalisco, México. Fundación Ecológica Cuixmala, A. C. Universidad Nacional Autónoma de México, Instituto de Ecología, Instituto de Biología. Ciudad de México, México.

Ceballos, G., H. Zarza, and M. A. Steele. 2002. Xenomys nelsoni. Mammalian Species 704:1-3.

Degenhardt, W. G., C. W. Painter, and A. H. Price. 1996. Amphibians and reptiles of New Mexico. University of New Mexico Press. New Mexico, U.S.A.

Domínguez-Castellanos, Y., F. Pimentel, and G. Ceballos. 2007. Uso de hábitat de roedores arborícolas en la selva seca de la Reserva de la Biosfera Chamela - Cuixmala, Jalisco. Revista Mexicana de Mastozoología 11:21-40.

García-Oliva, E., A. Camoua, And J. M. MaAss. 2002. El clima de la región central de la costa del Pacifico mexicano. Pp. 3-10 in Historia natural de Chamela (Noguera, E. A., J. H. Vega, A. N. García, and M. Quesada, eds.). Instituto de Biología, Universidad Nacional Autónoma de México. Ciudad de México, México.

Godínez, E. G., And S. Guerrero. 2014. Los roedores de Jalisco, México: clave de determinación. Therya 5:633-678.

Hammerson, G. A., F. Mendoza-Quijano, J. Lee, J. Vazquez-Díaz, and G. E. Quintero-Díaz. 2015. Senticolis triaspis. The IUCN Red List of Threatened Species 2015: e.T190631A79915739. https:// dx.doi.org/10.2305/IUCN.UK.2015.RLTS.T190631A79915739. en. Downloaded on 26 August 2018.

López-Forment, C. W., C. Sánchez-Hernández, and B. VillaRamírez. 1971. Algunos mamíferos de la región de Chamela Jalisco. México. Anales del Instituto de Biología, Universidad Nacional Autónoma de México. Serie Zoología 42:99-106.

Miranda, A. 2002a. Diversidad, historia natural, ecología y conservación de los mamíferos de Chamela. Pp. 359-378 in Historia Natural de Chamela (Noguera, E. A., J. H. Vega, A. N. Garcia, and M. Quesada, eds.). Instituto de Biología, Universidad Nacional Autónoma de México. Ciudad de México, México.

Miranda, A. 2002b. Xenomys nelsoni Merriam 1892. Pp. 439440 in Historia natural de Chamela (Noguera, E. A., J. H. Vega, A. N. García, and M. Quesada, eds.). Instituto de Biología, Universidad Nacional Autónoma de México. Ciudad de México, México.

Radke, W. R., AND J. W. Malcom. 2005. Ecology and natural history of the Green Rat Snake at Leslie Canyon National Wildlife Refuge, Cochise County, Arizona. Pp. 434-437 in Connect- ing mountain islands and desert seas: biodiversity and management of the Madrean Archipelago II (Gottfried, G. J., B. S. Gebow, L. G. Eskew, and C. B. Edminster, eds.). Proceedings RMRS-P-36, Fort Collins, CO: US Department of Agriculture, Forest Service, Rocky Mountain Research Station. Arizona, U.S.A.

Radke, W. R., And J. W. Malcom. 2008. Ratsnake species. Herpetological Conservation and Biology 4:9-13.

Ramírez-Bautista, A. 1994. Manual y claves ilustradas de los anfibios y reptiles de la región de Chamela, Jalisco, México. Cuadernos del Instituto de Biología No. 23. Universidad Nacional Autónoma de México. Ciudad de México, México.

Schaldach, W. J. 1960. Xenomys nelsoni Merriam, sus relaciones y sus hábitos. Revista de la Sociedad Mexicana de Historia Natural 21:425-434.

Secretaría de Medio Ambiente y Recursos Naturales (SEMARNAT). 2010. Norma Oficial Mexicana NOM-059-SEMARNAT-2010. Que establece especificaciones sobre protección ambiental-Especies nativas de México de flora y fauna silvestresCategorías de riesgo y especificaciones para su inclusión, exclusión o cambio-Lista de especies en riesgo. México. 30 de diciembre de 2010.

Seigel, R. A., J. T. Collins, And S. S. Novak (eds). 1987. Snakes: ecology and evolutionary biology. Macmillan. New York, U.S.A.

Valdivia-Hoeflich, J. H., V. Rivera, and K. E. Stoner. 2005. The Citreoline Trogon as an ecosystem engineer. Biotropica 37:465-467.

VÁzquez, E. 2018. Xenomys nelsoni. The IUCN Red List of Threatened Species 2018: e.T23115A22359234. https://dx.doi. org/10.2305/IUCN.UK.2018-1.RLTS.T23115A22359234.en. Downloaded on 26 August 2018.

Associated editor: Consuelo Lorenzo

Submitted: December 16, 2019; Reviewed: January 27, 2020. Accepted:February 11, 2020; Published on line: March 4, 2020. 